\title{
Evolution of air quality in Morocco before and during the COVID-19 pandemic; comparative study \\ Loubna Bouhachlaf ${ }^{1 *}$, Fatimazahra MOUSLI ${ }^{1}$, and Souad El hajjaji ${ }^{1}$
}

${ }^{1}$ Laboratory of Spectroscopy, Molecular Modeling, Materials, Nanomaterial, Water and Environment, CERNE2D, Mohammed V University in Rabat, Faculty of Science, Avenue Ibn Battouta, BP1014, Agdal, Rabat, Morocco

\begin{abstract}
The epidemic of coronavirus is spreading all over the world, which is not only a health problem, but also affects the social sector, politics, the environment in various ways and the world economy. In response to the rapidly changing international epidemiological situation of COVID-19, several governments have imposed restrictions on the movement of people and vehicles and suspended industrial activities as a safety measure to reduce the spread of the virus and protect human health. This study aims to compare the state of air quality in Morocco, before the pandemic and during the lockdown situation of the Moroccan territory between March 2020 and June 2020.
\end{abstract}

\section{Introduction}

The Covid-19 is an emerging pandemic of an infectious new disease, caused by the coronavirus SARS-CoV-2, which appeared in Wuhan on November 17, 2019[1], before spreading around the world. The World Health Organization (WHO) first alerts the People's Republic of China and its other member states and then declares a public health emergency of international concern on January 30, 2020 [2]. The Covid-19 epidemic was declared a pandemic by the WHO on March 11, 2020, which calls for essential protective actions to prevent overcrowding in intensive care units and to strengthen preventive hygiene [3]. This global pandemic is causing a series of cancellations of sporting and cultural events around the world, the implementation by many countries of containment measures to curb the formation of new outbreaks of contagion and the closure of borders in many countries [4]. It also has effects in terms of social and economic instability due to the uncertainties and fears it brings to the global economy [6].

\section{The influence of COVID-19 pandemic on air pollution in Morocco}

The lockdown due to the health situation in the world and in Morocco linked to COVID-19 has reduced air and road traffic, resulting in lower energy consumption and lower demand for oil. These changes in transport activities and oil demand have a significant impact on the quality of the environment [7], indeed since the start of containment Morocco has

*Corresponding Author: loubna.bouhachlaf@um5s.net.ma 
experienced a change in the very significant reduction rate of atmospheric pollutants and an improvement. appreciable air quality, it is clearly improved, a preliminary assessment of the air quality has been drawn up at the level of the city of Marrakech and covering the period from November 2019 to April 8, 2020. The first results of this balance sheet show significant reduction rates. Air pollutants, in particular a decrease of $55 \%$ for nitrogen dioxide $\left(\mathrm{NO}_{2}\right)$, $70 \%$ for carbon monoxide (CO) and $67 \%$ for suspended particles [8]. One of the consequences is the establishment of lockdown measures to limit the spread of the virus should widely modify anthropogenic emissions of pollutants, both in terms of mass emitted and temporal variations. The change in these emissions should modify the concentrations of surface pollutants observed in the world and also in Morocco. This has been observed since the start of the lockdown, in particular through the analysis of the measurements resulting from the monitoring of air quality [9].

\section{$3 \quad$ Materials and Methods}

\subsection{Study area}

Morocco is an African country located in the extreme northwest of the continent (fig.1). It has a coastline on both the North Atlantic Ocean to the west and the Mediterranean Sea to the north. The capital is Rabat and the largest city is Casablanca. Morocco spans an area of $710850 \mathrm{~km}^{2}$ and has a population of over 36471769 inhabitants (2019) [10].

This assessment, based on the analysis of data from air quality monitoring stations, before, during and after the state of health emergency [11]. This assessment will allow for a more detailed analysis of the air pollution situation, including the baseline, to draw lessons and make recommendations to limit post-COVID19 air pollution [12].

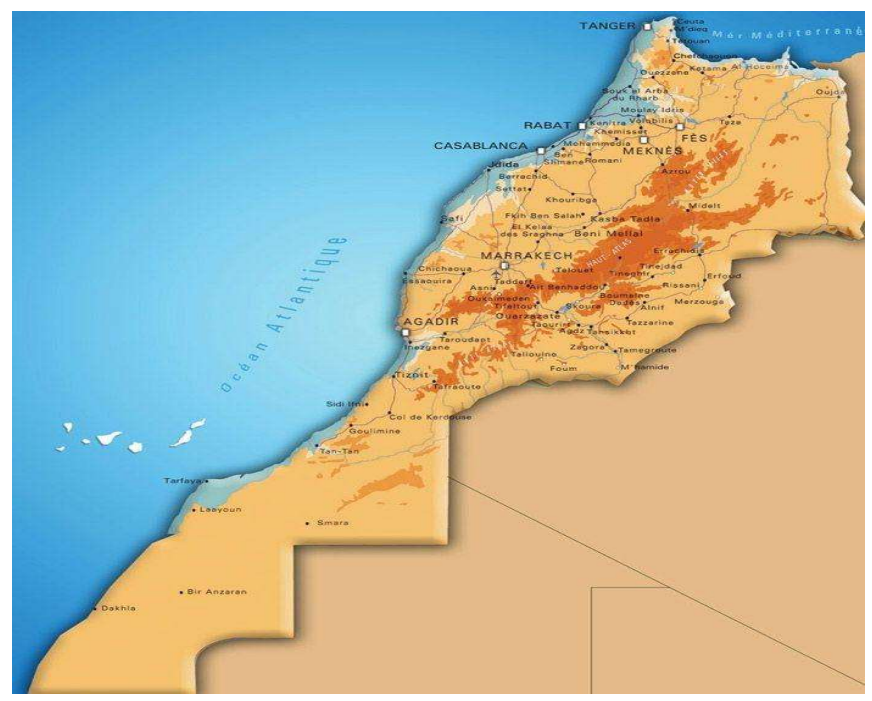

Fig.1. Map of Morocco. 


\subsection{Methodology}

The Ozone Monitoring Instrument is a Dutch and Finnish image spectrometer for ozone monitoring (Table 1). The instrument is designed to distinguish ozone from other atmospheric species. The OMI sensor has a spectral region of $264-504 \mathrm{~nm}$, a spectral resolution of $0.42 \mathrm{~nm}-0.63 \mathrm{~nm}$, and a resolution of $0.125 \times 0.1250$. The high spectral and spatial resolution of the instrument is key to the detection of urban-scale air pollution. The acquisition of measurements of the tropospheric and stratospheric levels of the Earth's atmosphere is the main objective of the instrument's mission. MERRA-2 stands for ModernEra Retrospective analysis for Research and Applications version 2. The MERRA project focuses on historical climate analyses for a wide range of weather and climate time scales and places the NASA Earth Observation System of Systems (EOS) series of observations in a climate context [13].

For the study of total column ozone, the TOMS-like OMTO3e product has been used. It selects the best pixel data from the good quality level-2 total column ozone data (OMTO3). This product data falls in the $0.25 \times 0.25$-degree global grids. For the study of the tropospheric column, NO2OMNO2d data product has been selected. It is a Level-3 Gridded Product where pixel-level data of good quality are falling into $0.25 \times 0.25$ degree global grids [14].

\section{$4 \quad$ Results and Discussion}

\subsection{Vicissitudes in $\mathrm{NO}_{2}$ emissions}

Nitrogen Dioxide $\left(\mathrm{NO}_{2}\right)$ is one of a group of gases nitrogen oxides (NOx). It is a dangerous pollutant in and of itself. Also while all of these gases are harmful to human health and the environment, $\mathrm{NO}_{2}$ is of greater concern. And also contributes to the formation of $\mathrm{PM}_{2.5}$ and ozone, two of the most dangerous forms of air pollution. Therefore, NASA has tracked by satellite and recorded the level of $\mathrm{NO}_{2}$ in the air (NASA, Global Nitrogen Dioxide Monitoring Home Page, 2020). NASA tracks two cities of Morocco mainly, Rabat, and Laayoune. Therefore, this study shows the satellite detected of the $\mathrm{NO}_{2}$ in the air across these cities to investigate the decline in the emission that is relatively correlated to the pandemic [15].

\section{4-1-1 $\mathrm{NO}_{2}$ measurement}

$\mathrm{NO}_{2}$ emission mostly originates after the burning of fuels and the consumption of automobiles. Therefore, to systematically evaluate whether the COVID-19 pandemic has an opposing effect on the concentration of $\mathrm{NO}_{2}$ in the air in three cities, $\mathrm{NO}_{2}$ was used as an estimation indicator [16].

NASA is responsible for expressing and realizing research in planetary science by using the ozone monitoring instrument (OMI) to collect the vicissitudes in Morocco's $\mathrm{NO}_{2}$ level before and after the pandemic.

Figure 2 illustrates the $\mathrm{NO}_{2}$ level in the air of the two cities over four years. The $\mathrm{NO}_{2}$ concentrations in the troposphere over cities show that the concentrations as of the end of 2019 are still the same as in 2018

\section{(A)}


Aura/OMI $\mathrm{NO}_{2}$ for Rabat,Morocco $(6.85 \mathrm{~W}, 33.97 \mathrm{~N})$

$1^{\circ}$ Latitude $\times 1^{\circ}$ Longitude box around city center

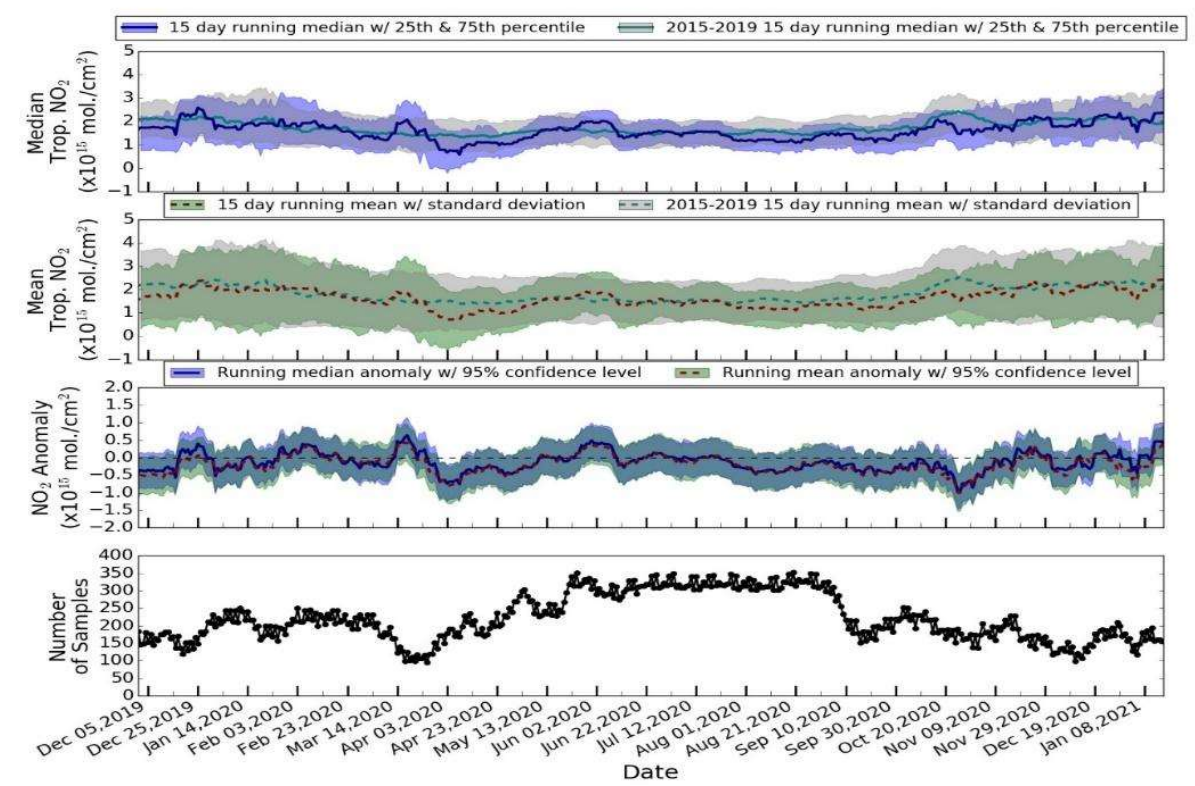

(B)

Aura/OMI $\mathrm{NO}_{2}$ for Laayoune,Western Sahara (13.20W, 27.15N)

$1^{\circ}$ Latitude $\times 1^{\circ}$ Longitude box around city center

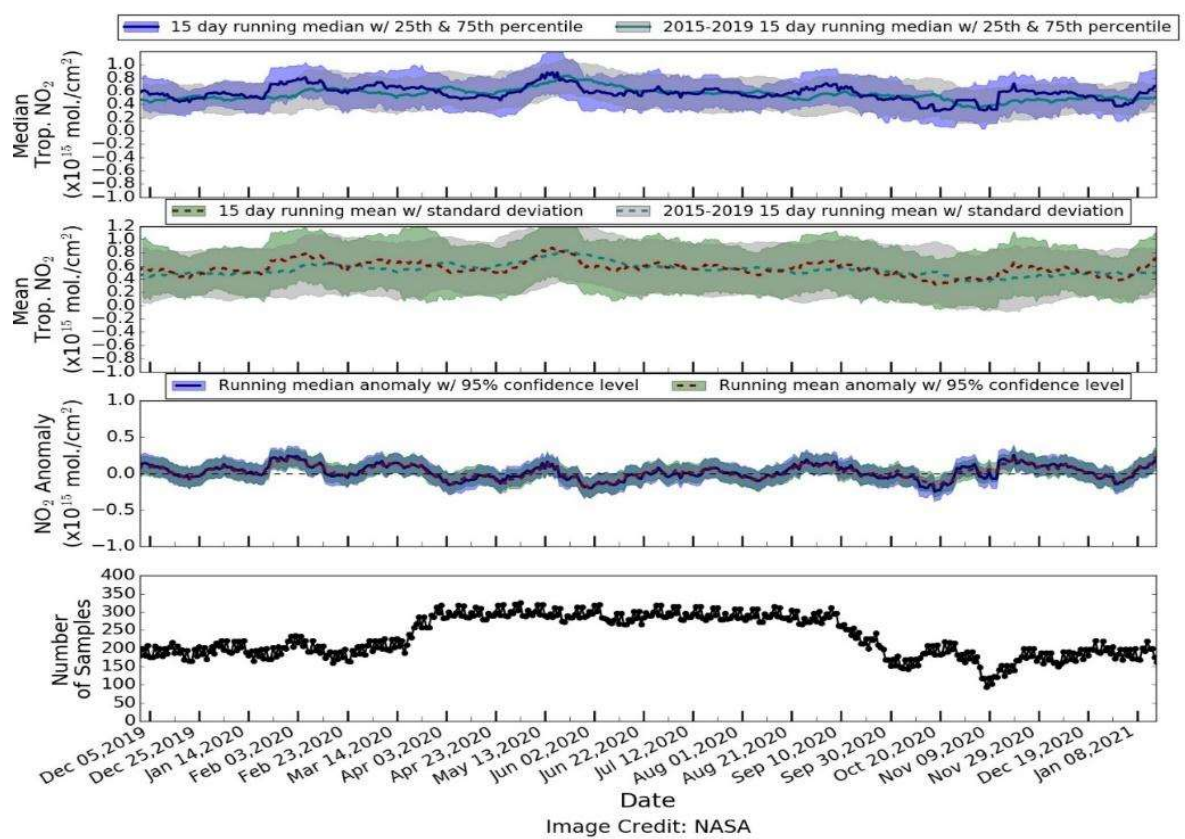

Fig. 2. Vicissitudes in $\mathrm{NO}_{2}$ emission levels in (A) Rabat, and (B) Laayoune, from 2015 to 2019.

Source (NASA- Rabat, and Laayoune, Morocco OMI data, 2020). 


\section{4-2- $\mathrm{NO}_{2}$ emissions in Morocco before, during, and the pandemic}

$\mathrm{NO}_{2}$ emissions in Morocco before, during, and after the pandemic gouvernements moroccan applied quarantine to avoid and control the spread of the COVID-19. Figures 3, 4, and 5 show the tropospheric screen on the OMI of NASA's Aura satellite composed of information on the $\mathrm{NO}_{2}$ level in the air of Morocco between January 1, 2020 and September 15, 2020.

Rabat shows the highest $\mathrm{NO}_{2}$ emission before the pandemic compared to other city laayoune due to the emission from the industriels activities and Traffic. Before the effect of the pandemic in the period between January 15, 2020 and mars 15,2020, the figures show that $\mathrm{NO}_{2}$ emission level in Morocco is high (fig.2.(A)). The effect of the pandemic is apparent on the reduction of $\mathrm{NO}_{2}$ in Rabat due to stop industriels activities and due to the transportation restriction. One possible reason for this finding was that during the pandemic, the vehicle exhaust and industry emission slowed down. [17]. The results of the examination show that the pandemic is seriously threatened public health; however, in the meanwhile, it contributes to reducing $\mathrm{NO}_{2}$ emissions significantly. This reduction as Morocco imposed strict restrictions to fight the pandemic, with the entire country closed. These restrictions not only slow local economic progress, nevertheless also efficiently condensed greenhouse gas (GHG) emissions. However, it is early to predict the long term of the contribution of COVID-19 pandemic on air pollution [18].
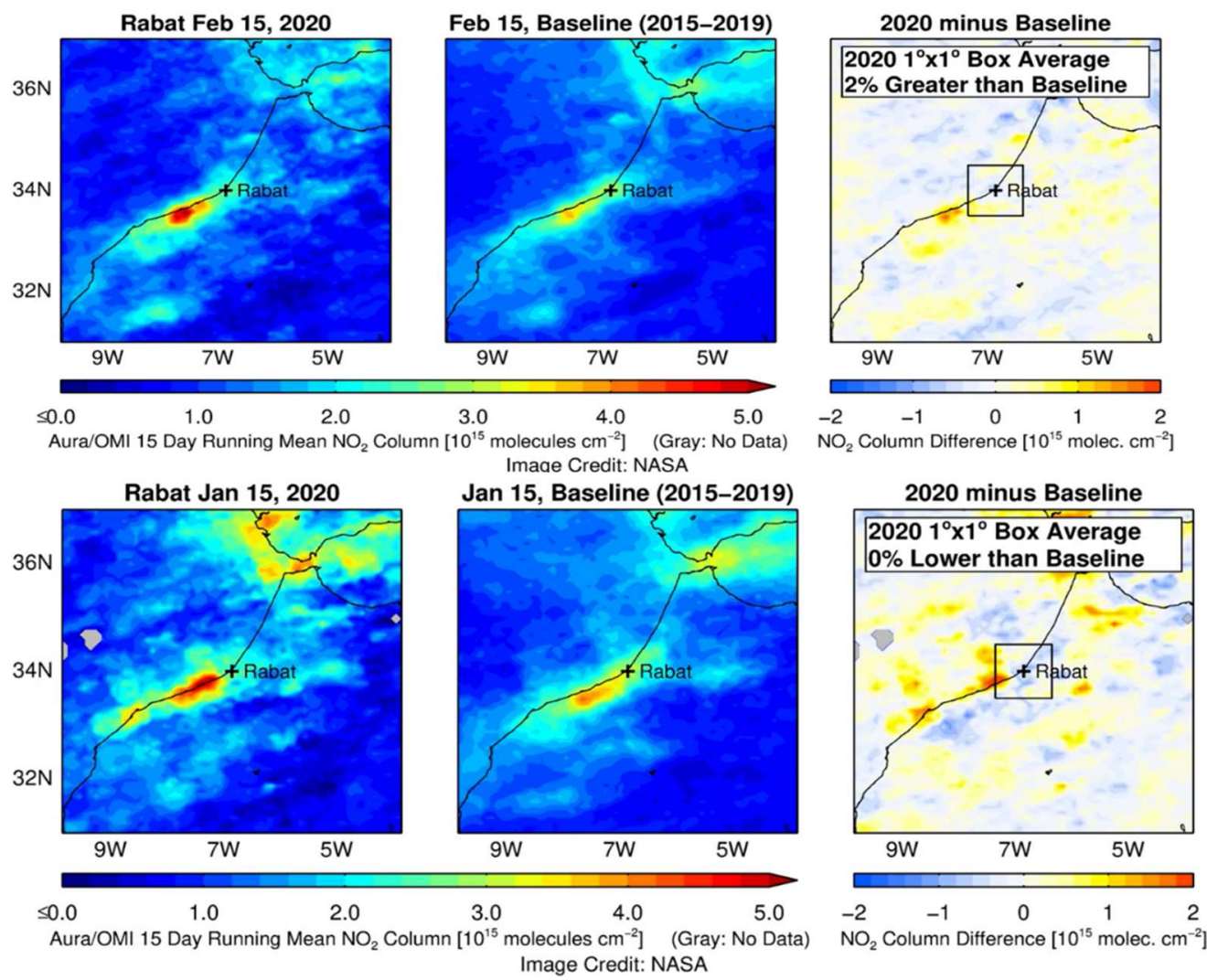

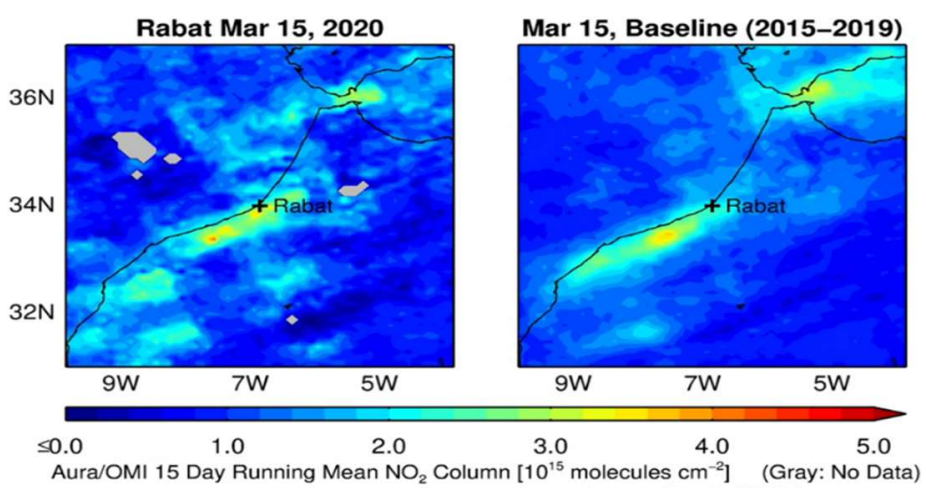
Imaae Credit: NASA
Mar 15, Baseline (2015-2019)

Data)

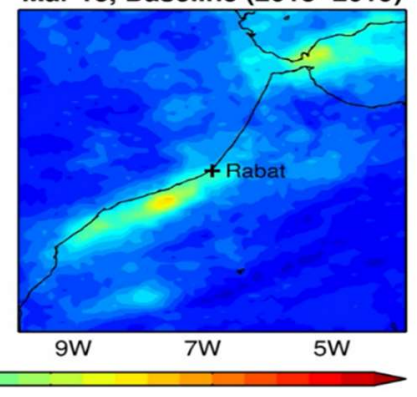

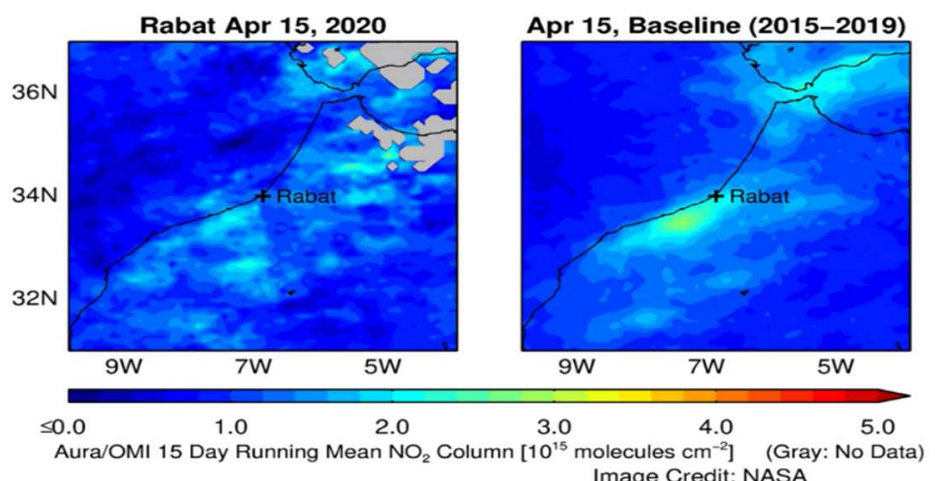

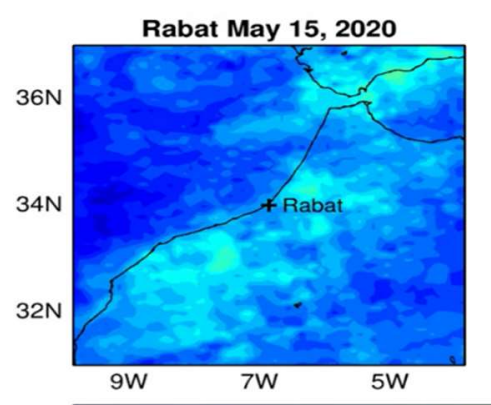

May 15, Baseline (2015-2019)

$\begin{array}{llllll}\leq 0.0 & 1.0 & 2.0 & 3.0 & 4.0 & 5.0\end{array}$

Aura/OMI 15 Day Running Mean $\mathrm{NO}_{2}$ Column $\left[10^{15}\right.$ molecules $\left.\mathrm{cm}^{-2}\right]$ (Gray: No Data)

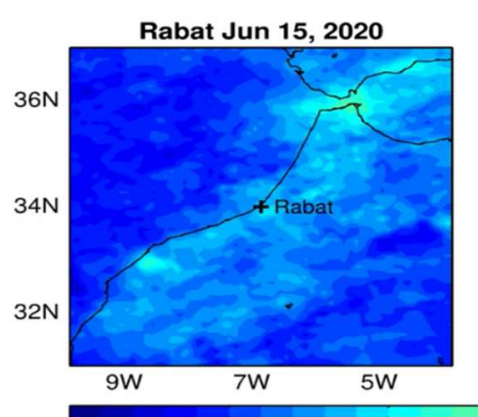

Imane Credit: NASA
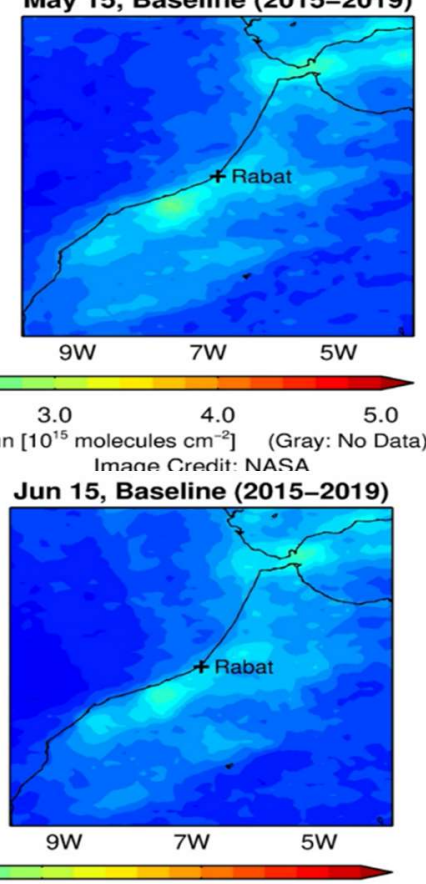

$\leq 0.0$

1.0

2.0

3.0

4.0

5.0

Aura/OMI 15 Day Running Mean NO 2 Column $\left[10^{15}\right.$ molecules $\left.\mathrm{cm}^{-2}\right]$ (Gray: No Data) Image Credit: NASA

2020 minus Baseline

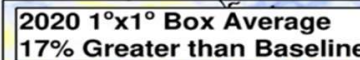
$17 \%$ Greater than Baseline
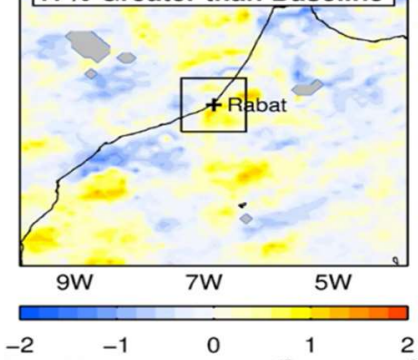

$\mathrm{NO}_{2}$ Column Difference $\left[10^{15}\right.$ molec. $\left.\mathrm{cm}^{-2}\right]$

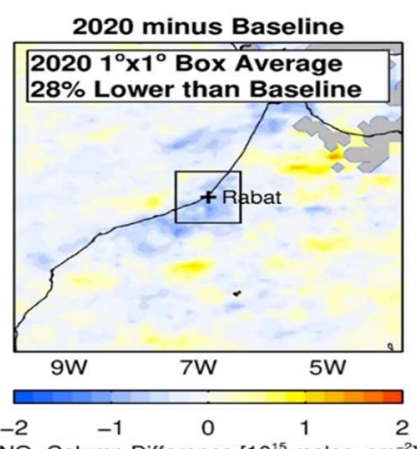

$\left.\begin{array}{ccccc}-2 & -1 & 0 & 1 & 2 \\ \mathrm{NO}_{2} & \text { Column } & \text { Difference } & {\left[10^{15}\right.} & \text { molec. } \\ \mathrm{cm}^{-2}\end{array}\right]$

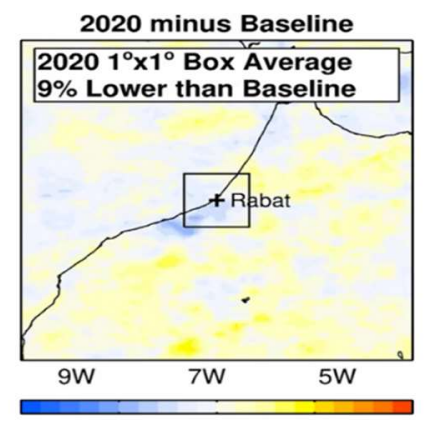

$\begin{array}{lllll}-2 & -1 & 0 & 1 & 2\end{array}$

$\mathrm{NO}_{2}$ Column Difference $\left[10^{15}\right.$ molec. $\mathrm{cm}^{-2}$ ]

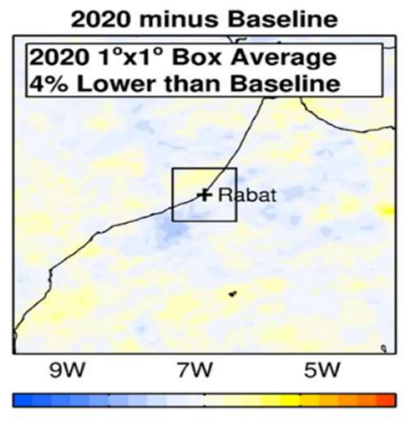

$\begin{array}{lllll}-2 & -1 & 0 & 1 & 2\end{array}$

$\mathrm{NO}_{2}$ Column Difference $\left[10^{15}\right.$ molec. $\left.\mathrm{cm}^{-2}\right]$ 


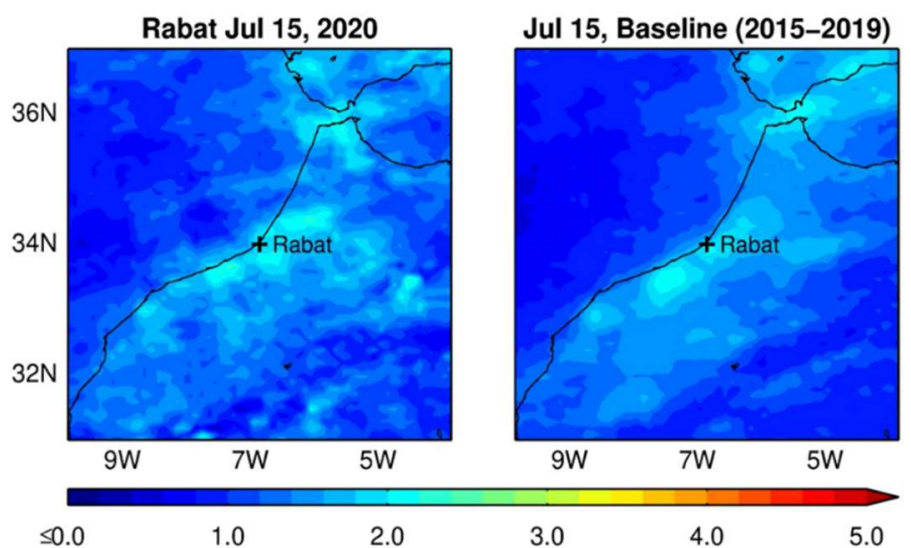

Aura/OMI 15 Day Running Mean $\mathrm{NO}_{2}$ Column $\left[10^{15}\right.$ molecules $\left.\mathrm{cm}^{-2}\right]$ (Gray: No Data) Imace Credit: NASA

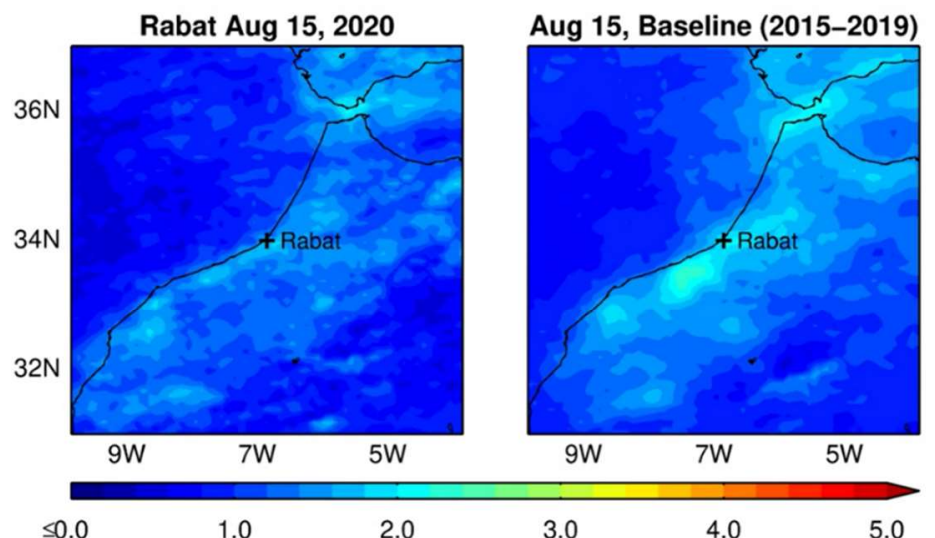

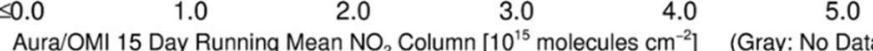
Image Credit: NASA

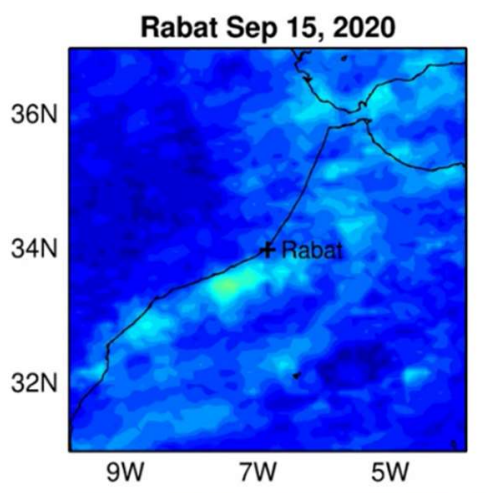

Sep 15, Baseline (2015-2019)

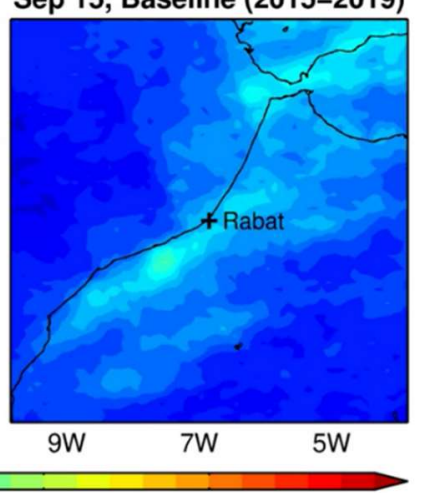

$\begin{array}{llllll}\leq 0.0 & 1.0 & 2.0 & 3.0 & 4.0 & 5.0\end{array}$

Aura/OMI 15 Day Running Mean $\mathrm{NO}_{2}$ Column $\left[10^{15}\right.$ molecules $\left.\mathrm{cm}^{-2}\right] \quad$ (Gray: No Data) Imaae Credit: NASA

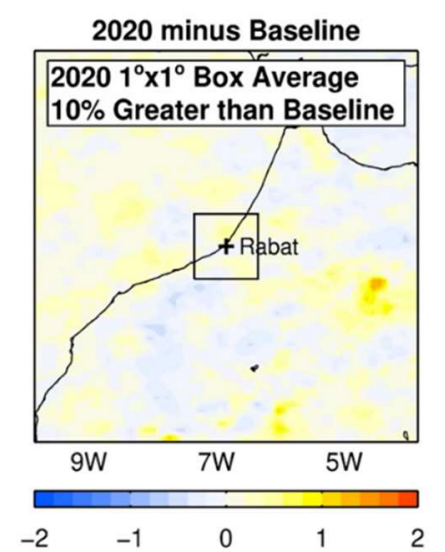

$\mathrm{NO}_{2}$ Column Difference $\left[10^{15}\right.$ molec. $\left.\mathrm{cm}^{-2}\right]$

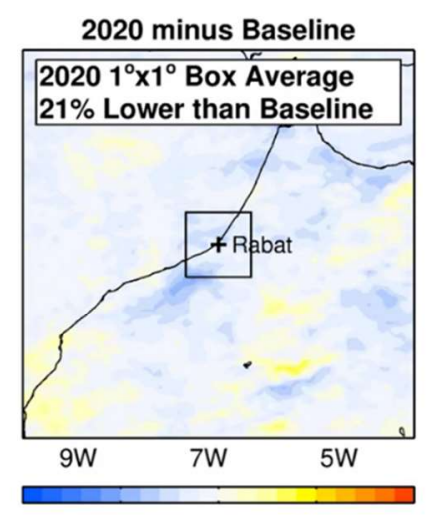

$\begin{array}{lllll}-2 & -1 & 0 & 1 & 2\end{array}$

$\mathrm{NO}_{2}$ Column Difference $\left[10^{15}\right.$ molec. $\left.\mathrm{cm}^{-2}\right]$

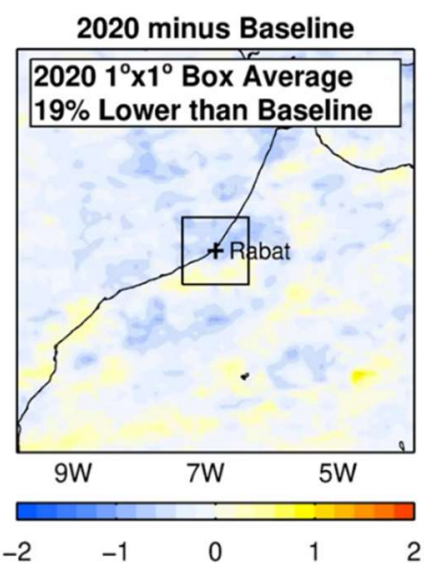

$\mathrm{NO}_{2}$ Column Difference $\left[10^{15}\right.$ molec. $\left.\mathrm{cm}^{-2}\right]$

Fig. 3. Vicissitudes in $\mathrm{NO}_{2}$ emission levels in Rabat from January 15, 2020 to September, 2020.

Source (NASA-Rabat OMI data, 2020) [19]. 


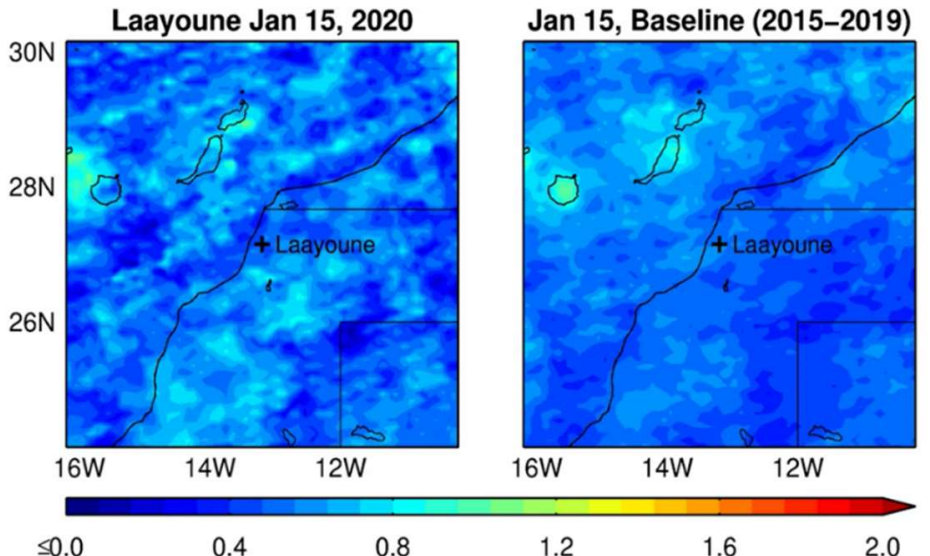

Aura/OMI 15 Day Running Mean $\mathrm{NO}_{2}$ Column $\left[10^{15}\right.$ molecules $\left.\mathrm{cm}^{-2}\right]$ (Gray: No Data)
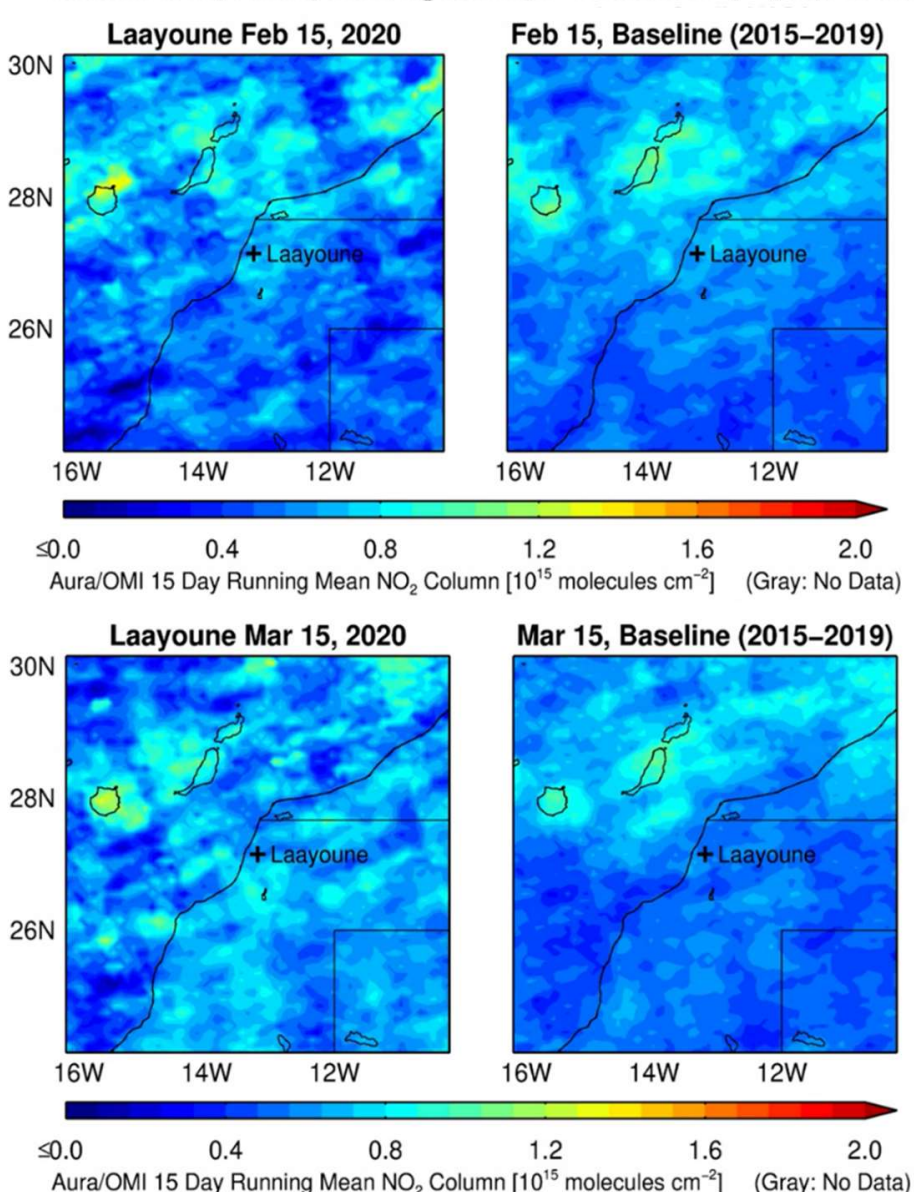

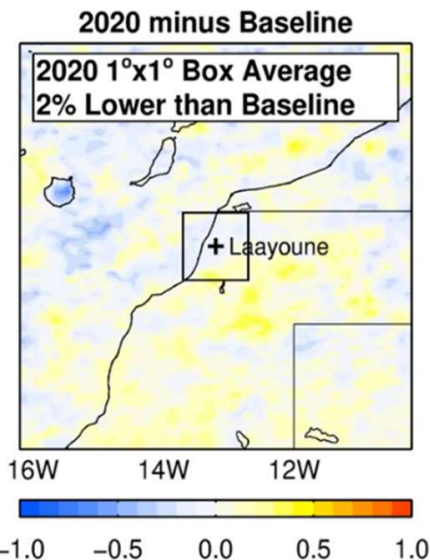

$\begin{array}{ccccc}-1.0 & -0.5 & 0.0 & 0.5 & 1.0 \\ \mathrm{NO}_{2} \text { Column Difference } & {\left[\begin{array}{ll}10^{15} \\ \text { molec. }\end{array} \mathrm{cm}^{-2}\right]}\end{array}$

2020 minus Baseline

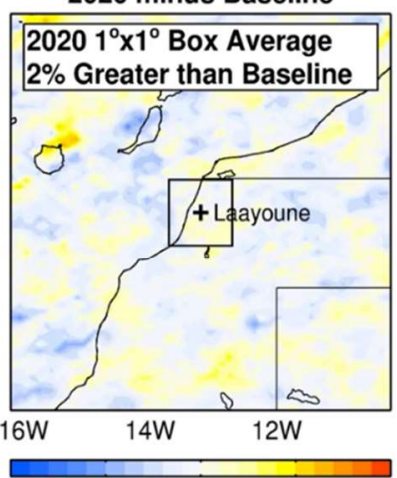

$\begin{array}{lllll}-1.0 & -0.5 & 0.0 & 0.5 & 1.0\end{array}$

$\mathrm{NO}_{2}$ Column Difference $\left[10^{15}\right.$ molec. $\left.\mathrm{cm}^{-2}\right]$

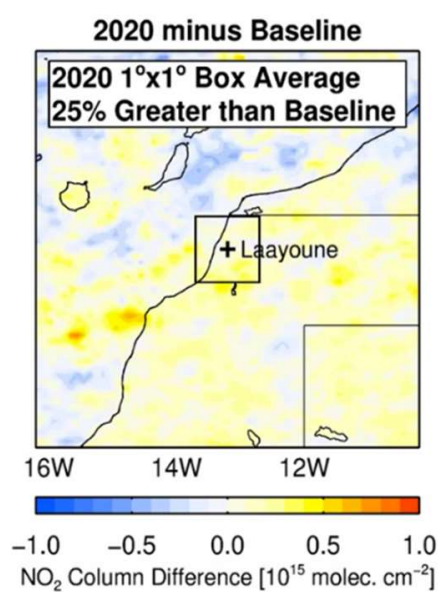




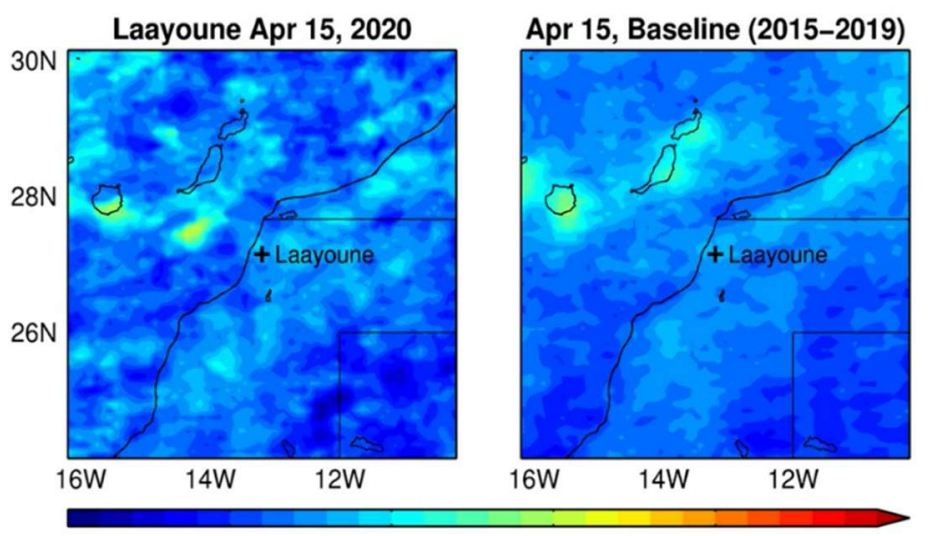

$\leq 0.0$

0.4

0.8

1.6

2.0

Aura/OMI 15 Day Running Mean $\mathrm{NO}_{2}$ Column $\left[10^{15}\right.$ molecules $\left.\mathrm{cm}^{-2}\right] \quad$ (Gray: No Data)

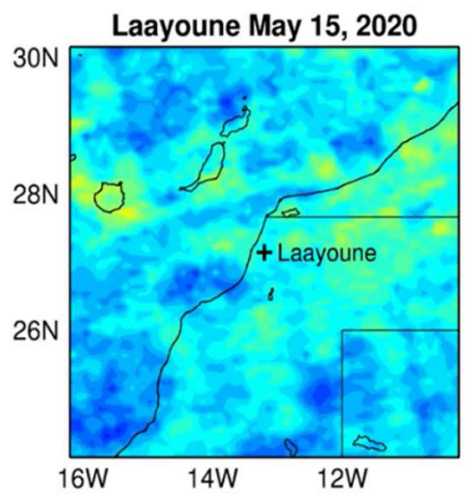

May 15, Baseline (2015-2019)

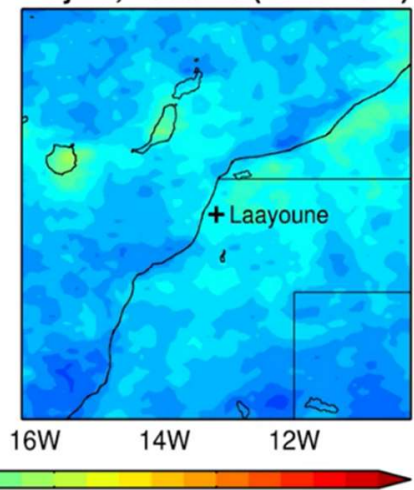

$\leq 0.0$

0.4

0.8

1.2

1.6

2.0

Aura/OMI 15 Day Running Mean NO, Column [10 $10^{15}$ molecules $\left.\mathrm{cm}^{-2}\right]$ (Gray: No Data)

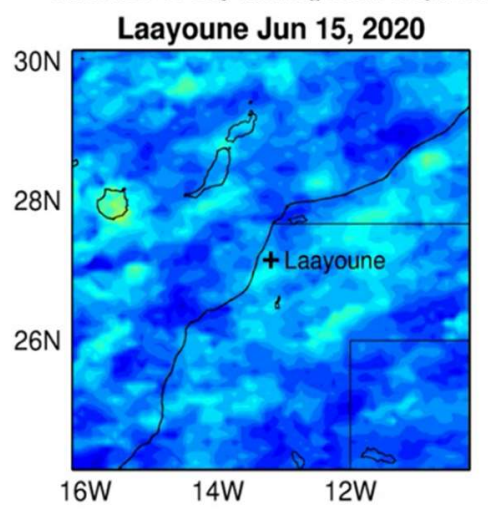

Jun 15, Baseline (2015-2019)

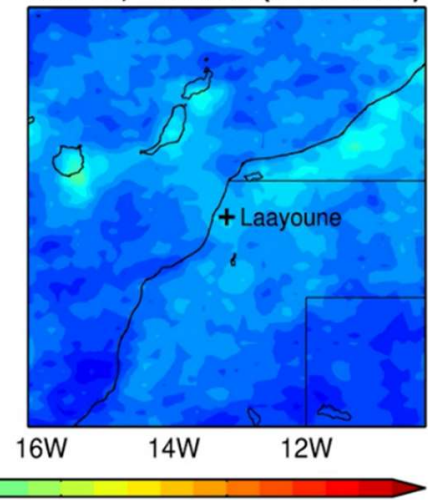

$\leq 0.0$

0.8

1.2

1.6

2.0

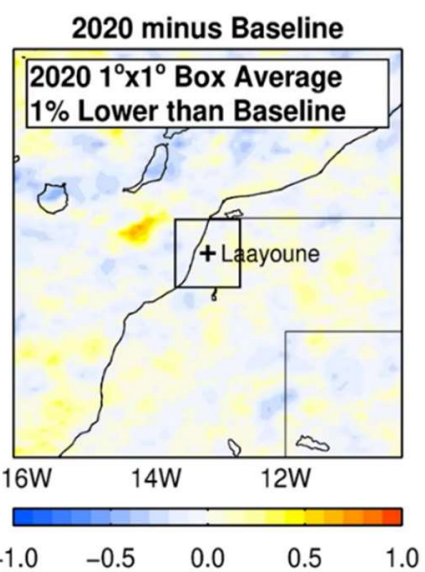

$\mathrm{NO}_{2}$ Column Difference $\left[10^{15}\right.$ molec. $\left.\mathrm{cm}^{-2}\right]$

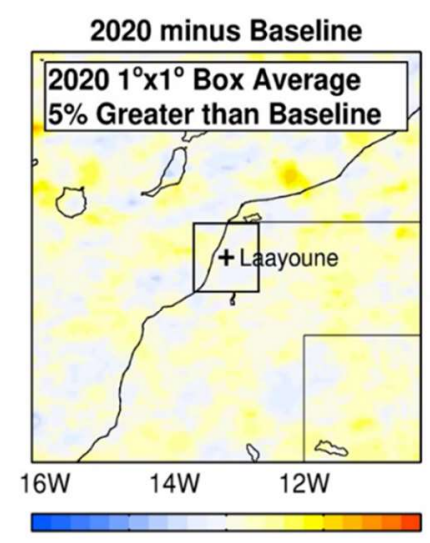

$\begin{array}{lllll}-1.0 & -0.5 & 0.0 & 0.5 & 1.0\end{array}$

$\mathrm{NO}$, Column Difference $\left[10^{15}\right.$ molec. $\left.\mathrm{cm}^{-2}\right]$

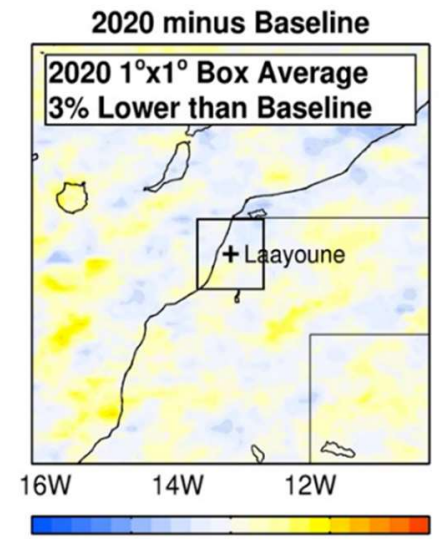

$\begin{array}{lllll}-1.0 & -0.5 & 0.0 & 0.5 & 1.0\end{array}$

$\mathrm{NO}_{2}$ Column Difference $\left[10^{15}\right.$ molec. $\left.\mathrm{cm}^{-2}\right]$ 

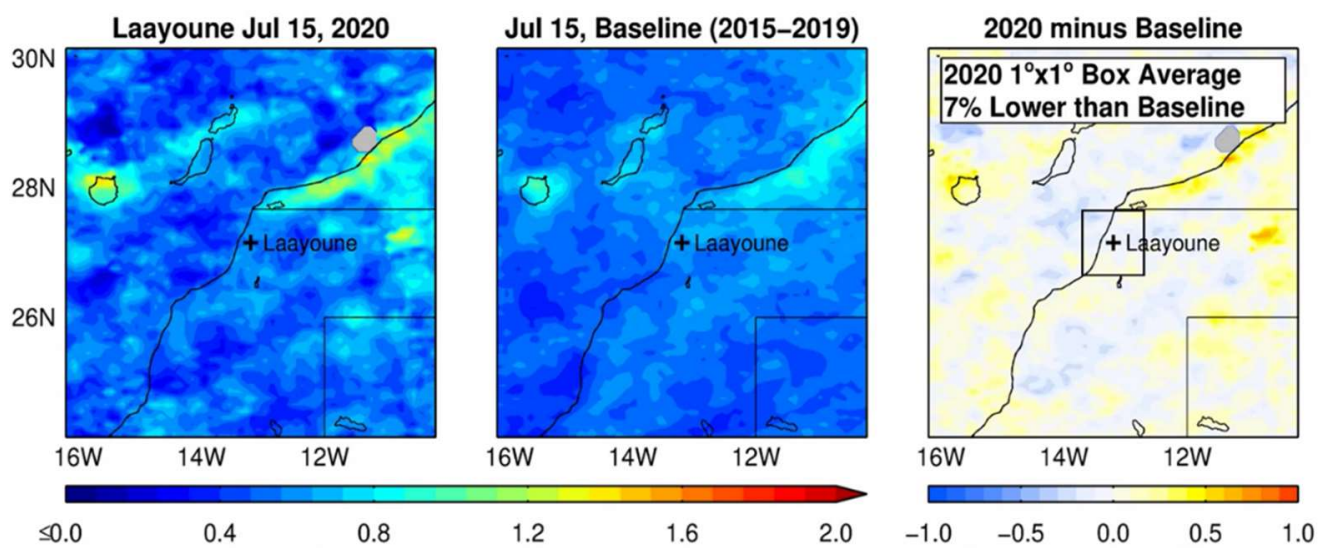

Aura/OMI 15 Day Running Mean $\mathrm{NO}_{2}$ Column $\left[10^{15}\right.$ molecules $\left.\mathrm{cm}^{-2}\right]$ (Gray: No Data)

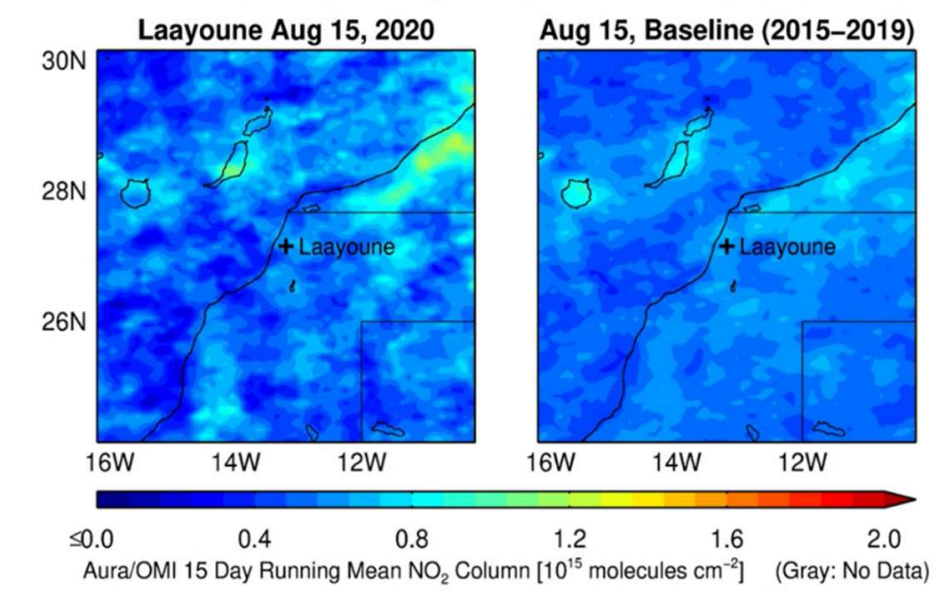

$\mathrm{NO}_{2}$ Column Difference $\left[10^{15}\right.$ molec. $\left.\mathrm{cm}^{-2}\right]$
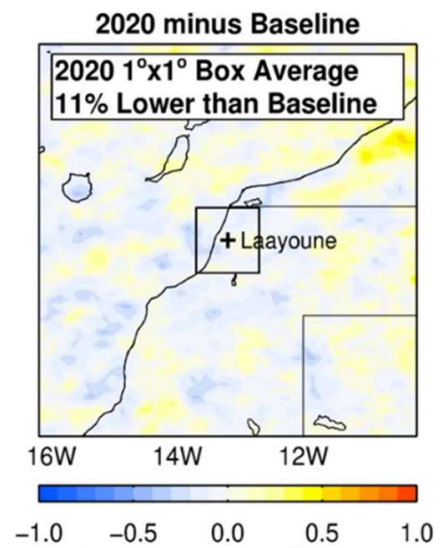

$\mathrm{NO}_{2}$ Column Difference $\left[10^{15}\right.$ molec. $\left.\mathrm{cm}^{-2}\right]$
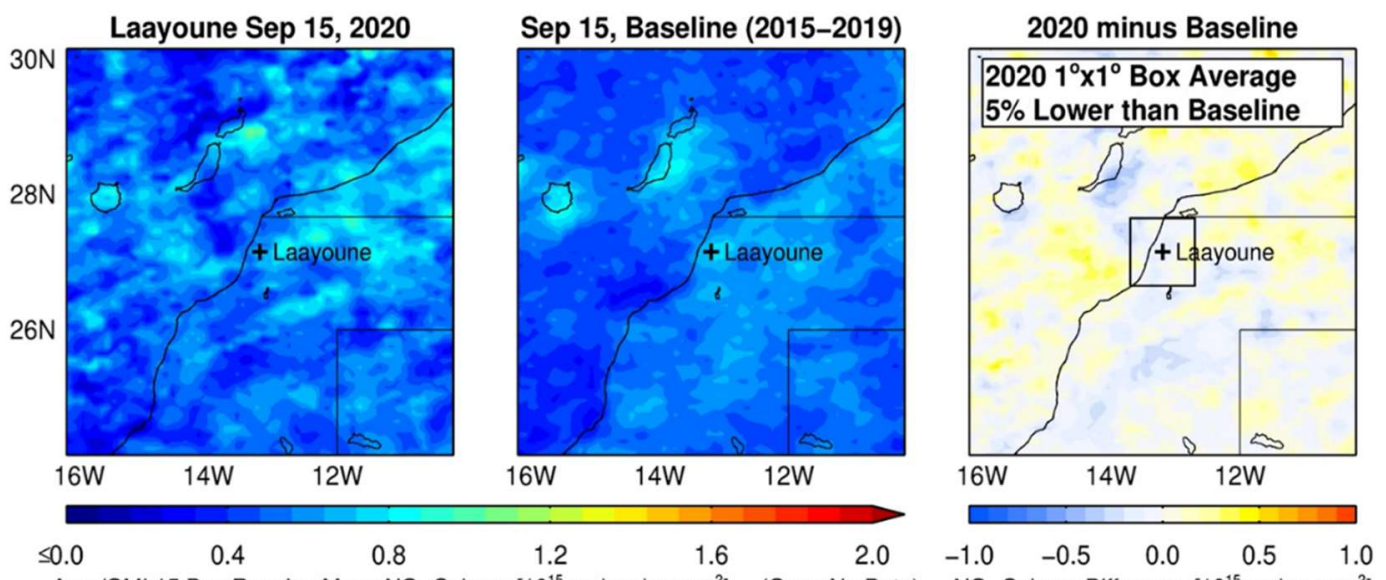

Aura/OMI 15 Day Running Mean $\mathrm{NO}_{2}$ Column $\left[10^{15}\right.$ molecules $\left.\mathrm{cm}^{-2}\right]$ (Gray: No Data) $\quad \mathrm{NO}_{2}$ Column Difference $\left[10^{15} \mathrm{molec} . \mathrm{cm}^{-2}\right]$

Fig. 4. Vicissitudes in NO2 emission levels in Laayoune from January 15, 2020 to September, 2020.

Source (NASA-Laayoune OMI data, 2020). 


\section{Conclusion}

This study provides an analysis of air quality changes in Morocco during the COVID19 pandemic for the period from March to June 2020. Satellite data comparing the levels of dioxide of azote concentrations after stopping savings indicate steep reductions. Data from the Sentinel 5-P satellite shows that, in confined areas, the average levels of $\mathrm{NO}_{2}$ between March 15 and May 15, 2020 were lower than the concentrations of June 2020 after lockdown. So we conclude that traffic restrictions applied during the quarantine for COVID-19 pandemic in Morocco were remarkably convincing in reducing emissions of $\mathrm{NO}_{\mathrm{x}}$. This reduction in ozone precursors reduces ozone.

\section{References}

1. P. Xu et al., High aspect ratio In2O3 nanowires: Synthesis, mechanism and $\mathrm{NO} 2$ gas-sensing properties. Sensors Actuators, B Chem., vol. 130, no. 2, pp. 802-808, (2008).

2. L. Luo, Y. Zhang, B. Pearson, Z. Ling, H. Yu, and X. Fu, On the security and data integrity of low-cost sensor networks for air quality monitoring," Sensors (Switzerland), vol. 18, no. 12, pp. 1-22, (2018).

3. M. A. Zaytar and C. El Amrani, MetOp Satellites Data Processing for Air Pollution Monitoring in Morocco. Int. J. Electr. Comput. Eng., vol. 8, no. 6, p. 4584, (2018).

4. C. Clerbaux and C. Clerbaux, Comité des sciences de l'environnement l'évolution de l'ozone atmosphérique Sophie Godin-Beekmann, no. (Octobre 2015).

5. N. Zhu et al., Morphogenesis and cytopathic effect of SARS-CoV-2 infection in human airway epithelial cells, Nat. Commun., vol. 11, no. 1, (2020).

6. L. Menut, B. Bessagnet, G. Siour, S. Mailler, R. Pennel, and A. Cholakian, Impact of lockdown measures to combat Covid-19 on air quality over western Europe, Sci. Total Environ., vol. 741, p. 140426, (2020).

7. B. El and F. Idrissi, Evaluation et étude des paramètres physico-chimiques de la pollution générée par les unités industrielles dans la région de Fès, no. April, (2020).

8. S. Lokhandwala and P. Gautam, Indirect impact of COVID-19 on environment: A brief study in Indian context, Environ. Res., vol. 188, no. April, p. 109807, (2020).

9. J. McNamara et al., COVID-19, Systemic Crisis, and Possible Implications for the Wild Meat Trade in Sub-Saharan Africa, Environ. Resour. Econ., vol. 76, no. 4, pp. 1045-1066, (2020).

10. J. B. Renard et al., Origins and spatial distribution of non-pure sulfate particles (Nsps) in the stratosphere detected by the balloon-borne light optical aerosols counter (loac), Atmosphere (Basel). vol. 11, no. 10, (2020).

11. M. Akram, M. Amrani, and C. El, "Air2Day: An Air Quality Monitoring Adviser in Morocco," Int. J. Comput. Appl., vol. 181, no. 17, pp. 1-6, (2018). 
12. S. Muhammad, X. Long, and M. Salman, COVID-19 pandemic and environmental pollution: A blessing in disguise? Sci. Total Environ. vol. 728, p. 138820, (2020).

13. A. Metya, P. Dagupta, S. Halder, S. Chakraborty, and Y. K. Tiwari, COVID-19 lockdowns improve air quality in the South-East Asian regions, as seen by the remote sensing satellites,Aerosol Air Qual. Res., vol. 20, no. 8, pp. 1772-1782, (2020).

14. S. Haddout and K. L. Priya, Unveiling the causes of reduction in troposphere NO2 in two cities of Morocco during COVID-19 lockdown, Environ. Forensics, vol. 0, no. 0, pp. 1-4, (2020).

15. T. Naciri and H. Hassani. COVID-19 national lockdown in Morocco: impacts on air quality 1 and public health. medRxiv, vol. 8106, p. 2020.07.05.20146589, (2020).

16. NASA earth observatory. Available from https://earthobservatory.nasa.gov/global_maps/MOD_LSTD_M/MOD_NDVI_M.

17. National Aeronautics and Space Administration Goddard Space Flight Center (NASA) 2019. Global Nitrogen Dioxide Monitoring Home Page, Africa OMI data. Available at: https://so2.gsfc.nasa.gov/no2/pix/regionals/Africa/Africa.html

18. KF Boersma, HJ Eskes, RJ Dirksen, RJ Van Der A, JP Veefkind. An improved tropospheric $\mathrm{NO}_{2}$ column retrieval algorithm for the Ozone monitoring instrument Atmos. Meas. Tech. 4 1905-28, (2011). 